\title{
Utopia in a liberal world facing crisis. Analysis of the new «grammars of change»
}

\author{
La utopía en un mundo liberal enfrentado a la crisis. Análisis \\ de las nuevas «gramáticas del cambio»
}

\author{
NICOLAS MARQUIS \\ UNIVERSITÉ SAINT-LOUIS - BRUXELLES
}

Artículo recibido el / Article received: 27-10-2013

Artículo aceptado el / Article accepted: 19-02-2014

ABSTRACT: The decline of utopia in some western intellectual environments has become an object of interest for scientists and essayists in these last few years. Yet, little has been done to analyze the common sense production of utopias or dystopias. This article will make use of the results of a statistical survey $(n=2774)$ to describe what can be called, in reference to Wittgenstein's philosophy, «the grammars of change», i.e., a more or less shared representation of «what is wrong» with society, but also of the real or illusionary possibilities to transform society. The article focuses on a striking line of tension. While some people still value political action as the bearer of a possible change, most interviewees consider it obsolete and unreliable. These people, who are so skeptical about politics, tend on the contrary to (over)invest in the idea that the power of change lies within the individual, in everybody's changing their own values and attitudes.

Keywords: sociology of individualism, grammars of change, self-help, utopia, faith in politics, liberal societies.

RESUMEN: El declive de las utopías entre ciertos sectores intelectuales occidentales se ha convertido en objeto de interés científico y ensayístico en los últimos años, a pesar de lo cual no se han realizado suficientes análisis sobre la producción del sentido común en relación a las utopías y distopías. El presente artículo utiliza los resultados de una encuesta estadística $(n=2774)$ para describir lo que podrían denominarse, siguiendo la filosofía de Wittgenstein, las «gramáticas del cambio», es decir, la representación, en mayor o menor medida, común de «lo que está mal» en la sociedad, aunque también de las posibilidades reales o ilusorias de transformación de la misma. El artículo se centra en una notable línea de 
tensión: mientras que algunas personas todavía valoran la acción política como motor posible de cambio, la mayoría de los entrevistados la consideran obsoleta y poco fiable. Estos últimos, escépticos con la política, tienden, por el contrario, a (sobre)valorar la idea de que el poder de cambio reside en los individuos, en que cada uno cambie sus propios valores y comportamientos.

Palabras clave: sociología del individualismo, gramáticas del cambio, autoayuda, utopía, confianza en la política, sociedades liberales.

\section{Introduction: On the merits of a sociological view of lay usage of the discourse about «the crisis»}

Asserting that the world is in crisis will produce very little disagreement today. The language of crisis has indeed permeated most aspects of our lives. It carries with it representations of the worlds, upwellings of our imaginations as to what drags the world into a crisis, but also statements about possible ways of exiting the crisis.

What is a crisis? As of what moment can one speak of a «state of crisis»? Unlike what a positivistic perspective might lead one to believe, there are no objective criteria or cut-offs for defining the moment that one enters a crisis. This is particularly by true of economic crises. As Frederic Lordon (2009, 2011) shows, the economic sciences themselves have great difficulty thinking through what a crisis is. This makes it one of the most poorly constructed concepts in existence. From a social science perspective, studying a «crisis» is thus inseparable from studying the way the crisis fits into the layperson's social representations. In other words, we must ask, in the manner of the pragmatist philosopher William James, what difference the presence of this notion in our representations and social affects makes in the way we live.

What does this concern about the «crisis» span when it comes not from scientists, philosophers, politicians, or opinion leaders, but from «John and Jane Doe»? We can assert without going too far out on a limb that whilst the idea of «crisis» is the subject of academic debate, it is still infinitely fuzzier in its common sense acceptation. For the ordinary citizen, it is as much economic as it is social, environmental, moral, civilizational, and so on. The abundance of meanings around the concern that is labelled the «crisis issue» is such that the expression could be termed a «floating signifier», to borrow from the anthropologist Claude Levi-Strauss's concept (1950). There is 
nothing pejorative about this term. It merely highlights the following fact: the effectiveness of a notion, that is to say, its success in a culture, is at least partly connected to the multiplicity of its possible uses or, to state it differently, to the intrinsic semantic vacuum that characterizes it. Indeed, in common parlance, the notion of crisis, even if it is qualified as an economic one, is used to refer to much more than a problem of resource distribution or structural contradictions in the capitalistic system. In using it, people speak of unbridled liberalism, individualism, loss of landmarks, materials, etc.

The general thesis of this article is precisely that «crisis» terminology is a cultural resource (Illouz, 2008) that serves as a pressure valve for expressing the various worries that are specific to individualistic liberal-democratic societies (Ehrenberg, 2010). This discourse makes it possible to visualize and to retranslate certain (real or assumed) difficulties of living together into the liberal vocabulary of autonomy, individual responsibility, and the common good.

The sociological dissection of the ways the notion of «crisis» is used enables one to reveal a "grammar of change» amongst its users, i.e., a more or less shared representation of «what is wrong» with society, of the "causes of the uneasiness» or «crises» that it experiences, but also of the real or illusionary possibilities for transforming society in a more or less well-thought-out and organized manner. This prompts us to challenge our indigenous conceptions of «the good life» and «living together in the world».

The article is organized as follows: first, I shall present my methodological approach, along with a discussion of the positions that the specific corpus led me to take. Second, I shall present this «grammar of change.» Thirdly, I shall focus on a particularly interesting question, namely, upon whom, depending on the individual, does responsibility for resolving the crisis lie? One line of tension is of particular interest in this regard, namely, the one that concerns the place of politics and political action (in these representations of common meanings) as a potential agent of change in society. Finally, in the fourth and last part we shall see what these grammars of change borrow from the liberal atmosphere that has swept through our society at the same time as they take this (neo-)liberalism as a main target of criticism.

\section{Methodology and survey material}

This demonstration is based on the results of a recent Internet survey. The questionnaire comprised some 150 questions concerning the respondents' 
values, representations, and behaviours primarily in the fields of the economy, ecology, political involvement, involvement in associations, multiculturality, self-development, and spirituality.

Specifying the population segment targeted and the way the data were collected is indispensable so as to avoid misunderstandings about the scope of the findings presented here. The survey effectively targeted mostly Belgian individuals who could be assumed to be socialized with regard to (even interested in) a discourse of social change. The survey was effectively publicized via channels (magazines, newsletters, associations and agencies, etc.) likely to reach people involved in sustainable development, forms of alternative economies, or even think-tanks about the future of the world, ecology, and so on. The questionnaire could be consulted on the Internet during the first few months of 2012. In all, 2741 respondents filled out the questionnaire validly.

However, the large sample size must not lead us astray: the survey cannot claim to have any «representativity» (in the statistical sense of the term). The sample was not constructed by means of a random procedure for the simple reason that the target group, i.e., people already sensitized to issues of social change, is not identified. No database making it possible to construct a random sample (or to correct for bias in the sample) for such a segment exists. Consequently, given the way the survey was conducted (open access on the Internet), it is inevitably subject to the well-known problem of selfselection bias, since the respondents themselves chose to be part of the sample by answering the questionnaire (see Frippiat \& Marquis, 2010). There is no certainty that these respondents are representative of the individuals who did not take part because they either did not have access to the survey or did not want to answer the questions.

While keeping this point in mind, we must nevertheless guard against embracing a «fetishist» vision of statistical representativity. Like Olivier Martin (2009), I propose here to look at the issue from the opposite angle: while this survey cannot claim to speak for a population that is not defined, it is nevertheless an exploratory study that makes it possible to approach such a population for the first time. My wager is that it reveals more clearly than in other groups the symbolic logics that have the status of an ideal type as defined by Weber. Consequently, to be correct, I shall thus take care to talk about «proportion of the sample» rather than «proportion of a population» that cannot be defined by any other means. 
Table 1 gives a better idea of the sample's distribution with regard to some conventional socio-demographic variables. Notice the large proportion of women and of people having completed higher education (more than twelve years of schooling), as well as the small proportion of people under 30 .

Table 1. Socio-demographic characteristics of the sample

\begin{tabular}{|c|c|c|}
\hline Variable & No. of valid respondents & Percentage of total \\
\hline \multicolumn{3}{|l|}{ Gender } \\
\hline Female & 1891 & 69.0 \\
\hline Male & 849 & 31.0 \\
\hline Total & 2740 & 100 \\
\hline \multicolumn{3}{|l|}{ Age bracket } \\
\hline Under 30 & 393 & 14.3 \\
\hline $30-49$ years & 1148 & 41.9 \\
\hline $50+$ & 1199 & 43.8 \\
\hline Total & 2740 & 100 \\
\hline \multicolumn{3}{|l|}{ Net monthly income } \\
\hline 0-1000 EUR & 609 & 22.2 \\
\hline 1001-2000 EUR & 1429 & 52.2 \\
\hline 2001 EUR or more & 1220 & 44.5 \\
\hline Total & 2738 & 100 \\
\hline \multicolumn{3}{|c|}{ Highest completed level of instruction } \\
\hline 9 years or less & 122 & 4.5 \\
\hline 12 years & 473 & 17.3 \\
\hline more than 12 years & 2137 & 78.3 \\
\hline Total & 2732 & 100 \\
\hline \multicolumn{3}{|l|}{ Place of residence } \\
\hline Brussels & 751 & 28.1 \\
\hline Wallonia & 1525 & 57.0 \\
\hline
\end{tabular}




\begin{tabular}{lcc}
\multicolumn{1}{c}{ Variable } & No. of valid respondents & Percentage of total \\
\hline Flanders & 88 & 3.3 \\
Out of Belgium (mainly & 311 & 11.6 \\
France) & & $\mathbf{1 0 0}$ \\
Total & $\mathbf{2 6 7 5}$ &
\end{tabular}

The overwhelming majority of the respondents presented themselves as being better informed, more aware of, and more concerned about societal problems. What is more, many of the subjects declared that they were engaged in «work on themselves»: indeed, close to $90 \%$ agreed with the idea that they had embarked on a path of «personal development». The majority also agreed with the statement that they were sensitive to «the spiritual dimension of existence» (76.1\%), working on upgrading their «human potential» $(82.2 \%)$, working on their relationship with their own body (68.8\%), engaged in therapy $(68.3 \%)$, or even engaged in work on thinking about the «feminine and masculine values that inhabit them» $(75.4 \%)$. Finally, the majority of the respondents tended to think of themselves as different from others, better informed and more active than the average citizen, and even had no qualms asserting that they did not see eye to eye with the population at large.

\section{Grammar of change}

The term "grammar» is borrowed from the philosophy of Ludwig Wittgenstein (2004). A grammar structures what the philosopher calls «a language-game». This can be understood to be a set of terms that a group of individuals belonging to one culture mobilizes often spontaneously to give meaning to the surrounding world. The study of these language-games thus enables us to grasp our cultural and socially situated «forms of life». The idea of a «language-game» is to show indeed that one cannot understand an utterance or a way of representing the world if one is not aware of the social environment in which it takes place. It is definitely not a matter of determining whether individuals are right or wrong, but of understanding how they use cultural resources and discourse to fashion the world in which they live, and to determine the opportuneness of an action. To do this, Wittgenstein said, one must study the meanings of words as one would an engine, that it to say, when 
it is running. In our case, that means perceiving our respondents' reactions to various propositions about the state of the world.

\subsection{The idea of crisis and the causes of the general uneasiness}

In the grammars glimpsed in our respondents' answers, the idea that we are living in a society in crisis is definitely the most widespread idea, as is shown by the massive agreement with the deliberately fuzzy proposition «We are heading for disaster if we continue to live like this» (only 7.6\% of the individuals said that they rather disagreed or disagreed completely with this statement).

«We are heading for disaster if we continue to live like this»

\begin{tabular}{lllll} 
Valid responses & Number & Percent & $\begin{array}{c}\text { Running total of } \\
\text { percentages }\end{array}$ \\
& $\begin{array}{l}\text { Disagree com- } \\
\text { pletely }\end{array}$ & 10 & 0.4 & 0.4 \\
& $\begin{array}{l}\text { Rather dis- } \\
\text { agree }\end{array}$ & 37 & 1.3 & 1.7 \\
& $\begin{array}{l}\text { Neutral } \\
\text { Rather agree }\end{array}$ & 677 & 24.7 & 32.3 \\
& $\begin{array}{l}\text { Agree com- } \\
\text { pletely }\end{array}$ & 1857 & 67.7 & 100.0 \\
Total & $\mathbf{2 7 4 1}$ & $\mathbf{1 0 0 . 0}$ & \\
\hline
\end{tabular}

The degree of agreement with this proposition shows well the dominance of the common representation according to which we are at an unprecedented turning point in our history. It is nevertheless interesting to observe that, beyond this plebiscite, the respondents show themselves to be much more divided when they had to answer more specific questions about the nature of this crisis. Here, two aspects bear mentioning:

The first one can be expressed as follows: Is it possible to change the current system «from inside» by adding new principles to those that already 
exist, or is the only solution that of revolutionizing the current system's fundamentals to rebuild the system on new foundations? More specifically, is it possible to reconcile a capitalistic economy's interests and ecological needs? Our respondents' answers to this question are extraordinarily varied, to the point where this variable has the largest standard deviation in the battery of questions: $44.3 \%$ of the respondents disagreed with the idea, $17.5 \%$ were indifferent to it, and $39.2 \%$ supported it. Other variables questioning the possibility of changing the current system without a fundamental overhaul yielded identical distributions. The apparent agreement about the need for change thus must not mask the different ways that individuals envision the magnitude of said change.

«It is possible to reconcile the interests of a capitalistic economy and ecological needs»

\begin{tabular}{lllll} 
& Number & Percentage & $\begin{array}{l}\text { Running total } \\
\text { of percentages }\end{array}$ \\
\hline Valid & Disagree completely & 528 & 19.3 & 19.3 \\
& Rather disagree & 687 & 25.1 & 44.3 \\
& Indifferent & 480 & 17.5 & 61.8 \\
& Rather agree & 640 & 23.3 & 85.2 \\
& Agree completely & 406 & 14.8 & 100.0 \\
& Total & $\mathbf{2 7 4 1}$ & $\mathbf{1 0 0 . 0}$ & \\
\hline
\end{tabular}

The second aspect completes the first one. Beyond the general feeling of «crisis», the respondents' opinions as to the main causes of the situation that we are in were more divided. When they were asked to rank the threats that loomed over our world by order of importance (with 1 being the most important and 7 the least important), there was a general plebiscite for the predominance of the economic system as the leading threat. Second (and well behind the first one) came environmental destruction, followed - with the same interval - by the item concerning the increasing scarcity of resources available for humankind. The idea of a loss of meaning was in the middle, just after the 
problems linked to resource allocation, whilst the lack of personal development was seen as the least threatening item.

The main threats facing our world are...

\begin{tabular}{|c|c|c|}
\hline & Mean & Standard deviation \\
\hline The predominance of the economic system & 2.6746 & 1.68459 \\
\hline Destruction of the environment & 3.0467 & 1.66414 \\
\hline $\begin{array}{l}\text { Overpopulation, causing global famine, and } \\
\text { the problem of access to drinking water }\end{array}$ & 3,4677 & 1.73357 \\
\hline $\begin{array}{l}\text { The loss of meaning and the ambient mate- } \\
\text { rialism }\end{array}$ & 3.5108 & 1.89322 \\
\hline $\begin{array}{l}\text { Violence generated by conflicts and terror- } \\
\text { ism }\end{array}$ & 4.2999 & 1.75419 \\
\hline Poverty in rich countries & 5.3491 & 1.50071 \\
\hline $\begin{array}{l}\text { Absence of personal development in the } \\
\text { population }\end{array}$ & 5.6512 & 1.62985 \\
\hline $\mathrm{N}$ valid responses & 2741 & \\
\hline
\end{tabular}

\subsection{Is there still room for utopia?}

Exploring the grammars of change also entails looking at the two semantic dimensions of practical or indigenous representations of utopia as eutopia, i.e., "the good place», «the ideal society», and u-topia, «the place that does not exist», «the society that is impossible to achieve». Before dwelling on this point, a quick flash-back is required. For many intellectuals, the 20th century was marked by three hiatuses in the production of utopias in the Western world, to the point where catastrophe was seen as «the bad conscience of modernity» (Foessel, 2012 a: 666).

First, the completion of the separation between Church and State, which began with the philosophy of the Enlightenment and was confirmed in France 
by the Briant Act of 1905, confined belief in Heaven to the private sphere once and for all (Gauchet, 1985) and gave way to the celebration of Reason, which was supposed to enable man to free himself from the shackles of his «minority status» (Kant, 1792, Was ist Auflkärung?). The utopia of a «beyond» was replaced by a utopia made possible solely by the development of human abilities.

The second break corresponds to the fall of the «secular ideologies (or religions)» of Nazism and Marxism, each of which encapsulated hope for a new world accessible here below. Two notable consequences of this fall were discussed at length. First was the blow that the discovery of the atrocities that Hitler's and Stalin's regimes committed - rationally - struck the rationalist programme initiated by the Enlightenment (Dumont, 1976; de Lara, 2008). Second, the triumph of liberalism, crystallized by the end of the Cold War and fall of the Berlin Wall, was freed of the threatening alternative of Communism (De Munck, 1999). So, the world gradually became more and more disenchanted as «ideologies» - as Destutt de Tracy put it - disappeared. It would appear that the only thing remaining was a (neo-)liberal system that could destroy or take on board the criticism levelled at it (Boltanski \& Chiapello, 1999) and the stated utopia of which - actually a dystopia - was that of a Darwinian world in which collective structures had disappeared, everyone struggled against everyone, and exploitation knew no bounds (Bourdieu, 1998).

The third break consists of the gradual awareness of what could be called «the world's finiteness», in which it is understood that humankind henceforward has the power to destroy itself, as we have been led to believe by the development of weapons of mass destruction (see Anders, 2008), industrial and technological disasters (such as the Chernobyl accident - see Beck, 2001), and of course the many facets of the environmental problem (depletion of resources, pollution of the biosphere, destruction of the ozone layer, increase in the human population, etc.). ${ }^{1}$

What place can be given to utopias in this context? If we read what philosophers and sociologists have to say, three attitudes are currently competing on the field. The first one is that of cynicism. As revealed by Sloterdijk (1987) and Castoriadis (1975), it is the attitude espoused by those who, no longer believing in anything, not even in the possibility of progress through human reason, give up investing in change to adapt to the current

1. As attested by, for example, the report The limits to growth, published by the Club of Rome think-tank in 1972, several aspects of which reactivate some neo-Malthusian arguments (for more on this doctrine's resurgence, see Lemaitre, 2009). 
world, whilst gleaning as much personal advantage as they can as long as such possibilities are given them. The second attitude allegedly results from the transition from a social utopia (such as presented by More or Rabelais) to a «techno-utopia» (Musso, 2010). In this case, utopia is torn from the sociopolitical field to be nurtured by a scientism that prophesises that humankind's well-known problems will be solved by the development of knowledge («technoprophets»). The third attitude is that of «catastrophism»- also a dystopia - foreseeing a bleak future for humankind that is unable to understand and manage itself.

The opposition between «technoprophetism» and (biological or economic) «catastrophism» is highly visible in many discussions today. Although they share the reference to a current insufficient state (and to the crisis vocabulary), the announcement of a massive (imminent or more remote) change along with strong criticism of the fatal argument of necessity (which basically says, «If you'd been in our shoes, you wouldn't have done it differently» (Stengers, 2009)) is used by the leaders in place to justify all forms of status quo; the holders of each attitude accuse each other of unawareness and the inability to argue their case. Catastrophism puts itself forward as the emblem of a new lucidity, whereas its critics see in it only a form of conservatism that one must continue to counter by the search for progress that began in the Enlightenment. Some philosophers (inter alia Lecourt, 2003) believed that they could sum up this tension in the opposition between a specific form of humanism (confidence in human beings' abilities to think up new solutions, especially technical ones), which sees salvation in investing in research and development in particular and, more generally, in an «appeal to intelligence», on the one hand, and an unavowed form of anti-humanist asceticism (Gauchet, 1990), on the other hand, with catastrophism imagining humankind's self-limitation, even denial, of what it currently is as a necessity, whether humans impose this on themselves voluntarily («best-case scenario») or it occurs uncontrollably.

The corpus of material at our disposal enables us to discuss the picture outlined above to show that the grammar of change that was revealed by our respondents actually corresponds to none of the three typical attitudes (cynicism, techno-utopia, and catastrophism) described above.

\subsubsection{Optimist}

First of all, the concern for a world in crisis expressed by the respondents and crystallized in the idea that «we are heading for disaster if we continue to 
live like this» was generally accompanied by a form of enchanted optimism foreign to both the cynical attitude and the catastrophist perspective. The majority of the respondents believe in the possibility of an accessible «change for the better» for the world, humankind, and each of its members and stated that they could already see the seeds of such change. So, only $16.4 \%$ of the respondents stated that they did not agree with the idea that "something good will ultimately come out of the current context of crisis», whereas close to $50 \%$ said that they saw initiatives that showed that we were «on the right track».

«I think that something good will ultimately come out of the current crisis context»

\begin{tabular}{llccc} 
Valid & Number & Percent & $\begin{array}{r}\text { Running total } \\
\text { of percentages }\end{array}$ \\
responses & $\begin{array}{l}\text { Disagree com- } \\
\text { pletely }\end{array}$ & 98 & 3.6 & 3.6 \\
& Rather disagree & 351 & 12.8 & 16.4 \\
& Indifferent & 823 & 30.0 & 46.4 \\
& Rather agree & 1166 & 42.5 & 88.9 \\
& Agree completely & 303 & 11.1 & 100.0 \\
& Total & $\mathbf{2 7 4 1}$ & $\mathbf{1 0 0 . 0}$ & \\
\hline
\end{tabular}

\subsubsection{The paths of change}

How do these individuals imagine the ways that this change, which was recognised as necessary by all, and possible by the majority, come about? The following table gives the respondents' rankings of the most probable paths of change ( 1 being the most probable and 8 the least probable). 
The most probable paths of change are...

\begin{tabular}{|c|c|c|}
\hline & Mean & Standard deviation \\
\hline a change in the way the economy works & 2.9792 & 1.98827 \\
\hline $\begin{array}{l}\text { community action and new social move- } \\
\text { ments }\end{array}$ & 3.1609 & 1.65115 \\
\hline $\begin{array}{l}\text { actions taken individually by each of us } \\
\text { as citizens/consumers }\end{array}$ & 3.4593 & 1.74263 \\
\hline inner work by a large number of people & 4.0595 & 2.21057 \\
\hline the decisions taken by political entities & 4.8070 & 2.19363 \\
\hline a larger place taken by women & 5.2149 & 1.79358 \\
\hline scientific and technological progress & 5.5418 & 1.93550 \\
\hline $\begin{array}{l}\text { actions taken by other entities that do not } \\
\text { depend on people }\end{array}$ & 6.7775 & 1.83640 \\
\hline $\mathrm{N}$ valid responses & 2741 & \\
\hline
\end{tabular}

Several elements are worthwhile singling out for attention. First of all, a change in the way the economy works clearly stands out at the top of the ranking, just as the threat that the predominance of this system represented did in the previous ranking. The current context of economic crisis in which the world has been enmeshed since 2008 and the discourse that this generates definitely have weight in this plebiscite. Secondly, the «techno-utopia» mentioned above does not seem to strike a chord with the respondents, since scientific and technological progress was ranked next to last (mean ranking of 5.54 out of 8). Thirdly, the fifth place given to «decisions taken by political entities» (4.8/8) is surprising. Not only is this item in the bottom half of the table, but it is also preceded by three singular items, namely, community action, individual action, and inner work by a large number of people. So, whilst the absence of personal development was not perceived as threatening the world's future, working on oneself and individual and collective action are seen as having the ability to produce change well beyond the credibility that politicians can enjoy. This line of tension appears to be particularly interesting. That is why I propose to dwell upon it here and shall try to draw some conclusions from its examination. 


\section{Who will be the hoped-for agent of change?}

For many commentators and essayists who have examined the current situation (see, for example, Lordon's writings), the main question still up in the air is whether the crisis context will be a factor of paralysis in the struggle and a vector of divestment from the common weal by individuals too busy saving the little that they can scrounge for themselves (in this sense, a door opening onto a new «state of nature», one of war on everybody), or, on the contrary, will blaze a trail to action and lead to catastrophe in its etymological meaning of revolution. Here it is once again interesting to examine the grammars of change to see how our respondents assign responsibility for the change(s) to come.

\subsection{Disavowal of politicians}

Our respondents' rapports with «politics» in general are interesting to analyse, for they are highly revealing. ${ }^{2}$ The respondents were massively interested in local and global political issues (close to $80 \%$ of them agreed with this proposition). Yet, the lack of trust in «politics in general» is impressive. As the following table shows, only $6.1 \%$ of the respondents stated that they had faith in politics.

«Generally speaking, I have faith in politics»

\begin{tabular}{llrrc} 
Valid & Number & Percent & $\begin{array}{c}\text { Running total } \\
\text { of percentages }\end{array}$ \\
responses & Disagree completely & 1275 & 46.5 & 46.5 \\
& Rather disagree & 868 & 31.7 & 78.2 \\
& Indifferent & 432 & 15.8 & 93.9 \\
& Rather agree & 158 & 5.8 & 99.7 \\
& Agree completely & 8 & 0.3 & 100.0 \\
& Total & $\mathbf{2 7 4 1}$ & $\mathbf{1 0 0 . 0}$ & \\
\hline
\end{tabular}

2. There are obviously statistically significant differences between the positions of the $16 \%$ who are political activists and the remaining $84 \%$ of the sample. Unfortunately, we do not have room here to expound upon all aspects of this rich corpus and thus must treat these two subsamples together. 
This mistrust inevitably affects the belief in the possibility of changing things through political activism, to which only $43 \%$ of our respondents adhered. What is more, the readability and relevance of the system's categories were also challenged, for close to $40 \%$ of our respondents said that they felt that they belonged neither to the right nor the left, and more than $50 \%$ asserted that they considered the notions of right and left to be obsolete. However, the fact that politicians were considered overall to be untrustworthy and incapable (for example, $68 \%$ of the respondents thought that government could no longer regulate the economy) did not prevent the respondents from continuing massively to make many demands of their politicians: government should take steps to regulate financial transactions and businesses better, to control resources, to improve the educational system, and so on.

This disavowal of politics seems to be accompanied by the promotion of means of action, to wit, community action and «new social movements» on the one hand and individual actions (including work on oneself and personal development) on the other hand, that could be called apolitical, to the extent that their value comes precisely from the fact that they do not use the pathways of political action.

\subsection{Community action and new social movements}

It is easy to pick out from the respondents' positions the idea that the «Archimedes point» at which it becomes possible to produce change is «outside the system» - and, from their standpoint, politics seems to be part of the system. The respondents readily see themselves as members of a «new generation» and have the feeling of «belonging to it», of being "where the action is». They actually think of themselves as the linchpins of the change to come. So, $77 \%$ of them concurred with the idea that their activities (outside their work) participated in building a better world. The social movement that they envisioned would thus operate outside conventional institutionalized pathways (hence the frequent use of the adjective "alternative») and according to the model of contagion or capillarity up until an overall tipping point was reached (see the metaphor of the last drop). As the following table shows, close to $80 \%$ of the respondents believed that a minority of individuals could change things on its own. 
«A minority that thinks differently can make things change»

\begin{tabular}{llrrr} 
& Number & Percent & $\begin{array}{r}\text { Running total } \\
\text { of percentages }\end{array}$ \\
\hline $\begin{array}{l}\text { Valid } \\
\text { responses }\end{array}$ & Disagree completely & 47 & 1.7 & 1.7 \\
& Rather disagree & 218 & 8.0 & 9.7 \\
& Indifferent & 357 & 13.0 & 22.7 \\
& Rather agree & 1376 & 50.2 & 72.9 \\
Agree completely & 743 & 27.1 & 100.0 \\
Total & $\mathbf{2 7 4 1}$ & $\mathbf{1 0 0 , 0}$ & \\
\hline
\end{tabular}

\subsection{Working on oneself}

Even more astonishing is the number of respondents who seem to engage in individual action, self-help, personal development, or working on oneself as a factor of social change. Faith in the minority is backed up by faith in the individual and her/his abilities. For the needs of this article, personal development can be defined as a logical scheme (of meaning and action) whereby the individual, acting alone or in a group, can work on her/himself in order to mobilize until then unexplored «inner resources» for the purpose of improving certain aspects of her/his life and the world in which s/he lives. ${ }^{3}$ Whilst personal development may have a bad reputation in certain social strata, it was not at all perceived as something negative in this sample: only $10 \%$ of the respondents agreed with the proposition «personal development is above all the action of individuals who are concerned about themselves only», while $77 \%$ rejected it (and 13\% said that they were «Indifferent»). On the contrary, personal development enjoyed the «anti-establishment» connotation in which it is often wrapped. Why is self-improvement seen as having the virtue to change the world? The respondents gave several reasons (for example, $91.2 \%$ feel that «our future will hinge on the quality of human relations»), but they can be subsumed under the banners of «practical anthropology» and «practical

3. For a more extensive discussion of how it is possible to define «personal development» in social science, see Marquis (2012). 
cosmology» (Marquis, 2012) that are revealed by the respondents' grammars. These widespread symbolic formations can be understood as ways of conceiving human beings and the world to make them accessible to action. For most of our respondents, human beings were «basically good» (only $27.4 \%$ disagreed with this proposition), but «society is what warps certain human beings» (only $15 \%$ disagreed with this proposition). In this representation of the world, the respondents reactivated a very common old scheme of thinking that pits the «good savage» against the «bad product of civilisation». The sociologist Claudine Herzlich had already identified this scheme in 1969 in the general discourse surrounding health and illness: «society», in its common acception, is yet another floating signifier that is used to explain many problems. It is on the side of the artificial that contaminates us, whereas our inner being is the reservoir of what is natural and pure. So, it is interesting to observe that the majority of our respondents did not feel that the social environments in which they moved respected their inner beings.

\section{«I have the impression of living in a social environment that respects my deepest inner being»}

\begin{tabular}{lllll} 
& Number & Percent & $\begin{array}{c}\text { Running total } \\
\text { of percentages }\end{array}$ \\
$\begin{array}{l}\text { Valid } \\
\text { responses }\end{array}$ & Disagree completely & 434 & 15.8 & 15.8 \\
& Rather disagree & 1019 & 37.2 & 53.0 \\
& Indifferent & 602 & 22.0 & 75.0 \\
& Rather agree & 545 & 19.9 & 94.9 \\
& Agree completely & 141 & 5.1 & 100.0 \\
& Total & $\mathbf{2 7 4 1}$ & $\mathbf{1 0 0 , 0}$ & \\
\hline
\end{tabular}

Two consequences of this symbolic representation should be noted. First, the respondents assert a more monistic approach against the naturalistic ontology that separates man from nature (Descola, 2005): 95.2\% shared the view that «Earth is a huge organism with which we must live harmoniously», and $92.8 \%$ agreed with the proposition «The human being is part of nature and must not try to control it». There, too, «society» is what allegedly perverts 
human beings by cutting them off from a symbiotic relationship with the environment that it is imperative to restore.

The second consequence is even more interesting. In the respondents' grammar it is thus meaningful to work on oneself (on one's identity, inner being, values, true relationship with one's body or others, etc.) to «(re)find oneself», even - and even more so - if this work entails distancing oneself from «society», from «the system». As we have seen, a large proportion of the respondents in this sample announced that they were effectively engaged in personal development, in upgrading their human potential, etc. From their point of view, that is not a choice that we are free to make. «Developing oneself» is rather an obligation, as the following table shows.

\section{«Generally speaking, all human beings should try to develop themselves throughout their lives»}

\begin{tabular}{llccc} 
Valid & Number & Percent & $\begin{array}{r}\text { Running total } \\
\text { of percentages }\end{array}$ \\
responses & Disagree completely & 11 & 0.4 & 0.4 \\
& Rather disagree & 15 & 0.5 & 0.9 \\
& Indifferent & 175 & 6.4 & 7.3 \\
& Rather agree & 885 & 32.3 & 39.6 \\
& Agree completely & 1655 & 60.4 & 100.0 \\
Total & $\mathbf{2 7 4 1}$ & $\mathbf{1 0 0 . 0}$ & \\
\hline
\end{tabular}

This obligation is not just a matter of self-respect; it is also a matter of living in society. For these respondents, speaking of «the social responsibility of personal development or of working on oneself» is not an oxymoron. Indeed, it is possible to detect in this practical anthropology an equation between personal development and social development, as shown by the very broad support for the cliché ${ }^{4}$ according to which «being oneself already changes things».

4. There is nothing pejorative about this term. It is to be understood simply as an expression able to reflect a certain spirit of the times. 
«Being oneself already changes things»

\begin{tabular}{llccc} 
Valid & Number & Percentage & $\begin{array}{c}\text { Running total } \\
\text { of percentages }\end{array}$ \\
responses & $\begin{array}{l}\text { Disagree com- } \\
\text { pletely }\end{array}$ & 33 & 1.2 & 1.2 \\
& Rather disagree & 111 & 4.0 & 5.3 \\
& Indifferent & 463 & 16.9 & 22.1 \\
& Rather agree & 1075 & 39.2 & 61.4 \\
& Agree completely & 1059 & 38.6 & 100.0 \\
& & & & \\
\hline
\end{tabular}

\section{The elective affinities between personal development and the decline of politics}

Is there a connection between the decline of politics and politicians' credibility and (over)investment in the individual's or group's abilities seen in this grammar of change? That is what we shall analyse now. There are two complementary ways of interpreting the link between these two representations. The first one has to do with the structure of society (this time in the sociological sense of the term), and the second one has to do with our world's moral environment.

\subsection{How to act in a complex world?}

According to this first interpretation, we must look for the reason for this (new) way of envisioning social change in the hypercomplexity of modern society, in which the "causal chains» (to use Georg Simmel's expression) have become so long that it is often very difficult for us to understand who is responsible for what happens to us. So, a personnel manager may fire employees because s/he must meet profitability targets set on another continent to please a myriad of unknown, invisible shareholders (who might even include the fired employees!). So, we are often subject to systemic effects that no one 
truly controls (even though, of course, some have infinitely more possibilities than others to gain from them rather than suffering their consequences (see Boltanski, 2009)). Our respondents seem to share this feeling of an opaque society in which we no longer know very well where to act and whom to pressure to effect changes. The disparity between the responses to the following two assertions, which were presented one after the other in the questionnaire, is striking:

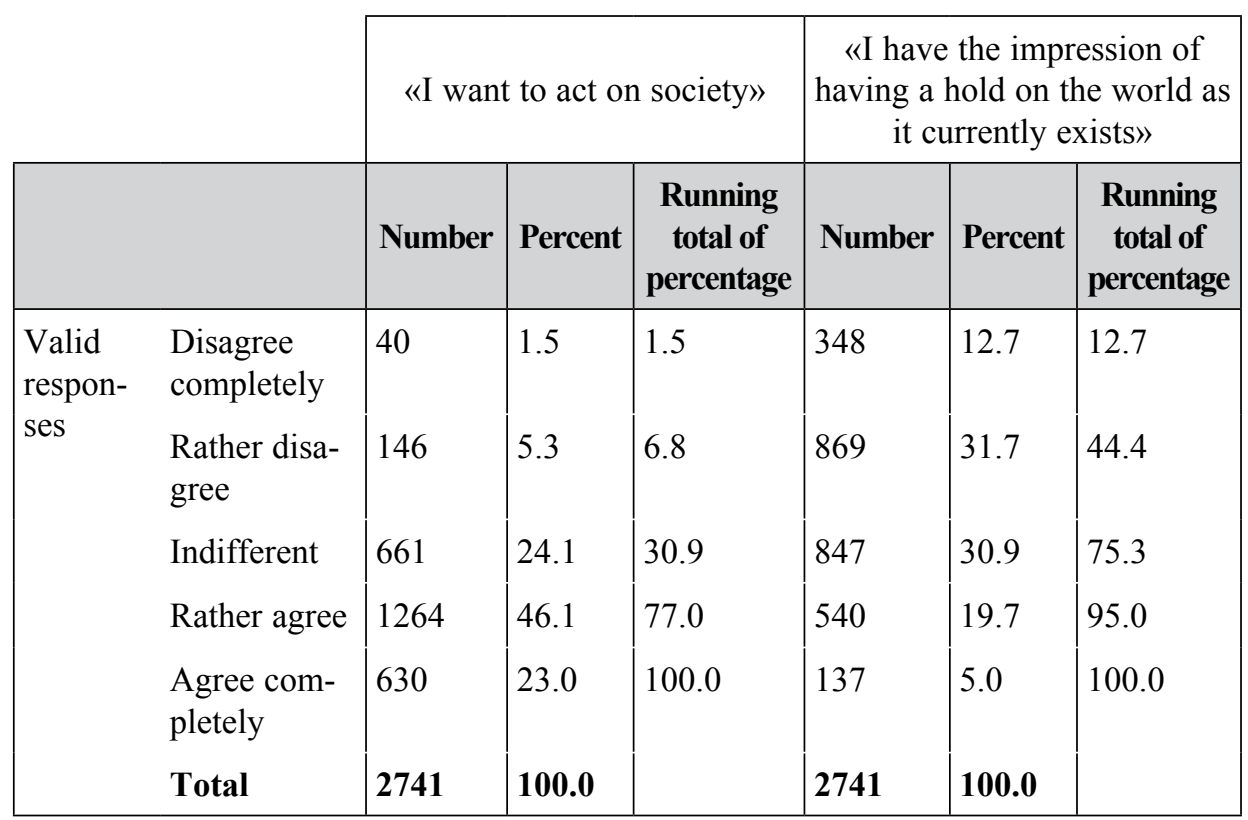

Whereas close to $70 \%$ of the respondents stated that they wanted to act on society, only $25 \%$ had the impression that they had a hold on the world as it is today. How do they reconcile this feeling of powerlessness with their faith in the possibility of a social change in which they might play a part? The answer seems obvious: by working on what is workable, that is to say, oneself to start off with, and possibly on our near and dear. From this point of view, believing in the virtue of personal development or of the action of small groups to produce social change turns out to be the logical, rational, and sensible consequence of the feeling of powerlessness that is generated by society's opaqueness. Similarly, their distrust of politics and politicians seems above 
all to mark disbelief as to the possibility of a conventional political plan being able to change a society on which it, too, ultimately has few holds.

Even though this answer appears to be obvious, understandable, and rational once it is put back into the context of complex societies, it has nonetheless upset many (French-speaking) sociologists for years. For such sociologists, there is a clear link between divestment from politics and overinvestment in work on oneself. The interesting writings on this subject include R. Castel's (1981) La gestion des risques. Thirty years ago this author was already wondering about the consequences of the following:

[...] when economic, social, and political options are beyond the subject's control, the psychological is endowed with a form of reality that is autonomised, if not autonomous. We are now facing a subjectivity that is all the more "free" as it manages only issues of minor importance. As social life has already divested, in many sectors, from options that go beyond staging the personal economy, the establishment of a psychologically saturated sociability creates the last theatre in which a relational culture unfolds, a culture that in such a case can have no other purpose than to reproduce itself. (Castel, 1981: 191 [italics added]). This thesis is definitely stimulating, but must be updated.

\subsection{A common foundation: the liberal understanding of the world}

I believe that this first interpretation must be backed up by a second one, an interpretation that adds the moral context (in Durkheim's sense of the word, i.e., shared mores) in which we live. We can posit that there is a much deeper elective affinity between the discourse around personal development and the grammar of change that is revealed by our respondents' remarks.

I should like to defend here the idea that if these sensitivities seem to a certain extent to go hand in hand, it is because they are rooted in the same philosophical tradition, that of liberalism. ${ }^{5}$ This may seem paradoxical, given that «liberalism» (once again a hollow signifier) is indeed a clear adversary, and claimed as such, of many of the individuals in the survey. Yet the grammars of change presented here support Ehrenberg's (2010) thesis, according to which the moral environment in which we live is paralysed with liberal representations from political philosophy (Locke, inter alia) at times,

5. Unfortunately, we do not have space here to go into the difference between economic and political liberalism, or even the difference between the American and French takes on liberalism. 
from the representation of society as a market (Smith, inter alia) at other times, or from doctrines celebrating the individual in action (Calvin's puritanism, Emerson's American transcendentalism, A. Maslow's humanist psychology, the currently popular currents that stress the power of the mind over ourselves and the world in general, such as psycho-cybernetics and positive psychology, and many other doctrines) ${ }^{6}$ at still other times. All of these representations have moulded our ways of representing ourselves and of claiming certain qualities.

Our moral environment can be called liberal because in it a certain type of behaviour is expected of individuals, that of autonomy. Ehrenberg (2010) describes our societies in a stimulating way as being societies of «autonomy as a condition», in which autonomous behaviour is no longer a state that one strives for (as was the case during the three decades of post-war prosperity), but a standard, a desirable social expectation, a presumed ability of each individual that the individual is asked to activate in a series of circumstances. The individual must thus be responsible for her/himself; otherwise s/he is liable to more or less formalised social sanctions. The social sciences have for years concerned themselves with the consequences of these new representations and practices in the area of the redistribution of wealth by the State. So, several sociologists have produced critiques of what today goes by the name of the «active social Welfare State», in which aid is no longer unconditional but contingent on the recipient's being able to prove her/his autonomous behaviour aimed at taking control of her/his life (see, for example, Vielle et al., 2005).

It is striking to see how much sociologists' often worried and critical views on this liberal moral environment and its hypothetical consequences differ from the way that our respondents readily endorse the structure of this discourse to apply it to other swatches of their lives (but, it is true, where the leitmotif of autonomy and individual responsibility does not take the form of a requirement imposed by others, as is the case of social aid in the age of the active social Welfare State). Indigenous representations of social change seem to be one of these swatches. They attest to the way that people think of the possibility for human beings to produce their own fates in the context of societies of «autonomy as a condition». Whether this is presented in an esoteric or non-esoteric, psychologising or non-psychologising vocabulary, the autonomous individual is considered in the grammars of change dissected here to be the basic atom of action (which can become collective by spreading from relation to relation). Of course, this is not a scientific hypothesis put forward by the respondents, but a moral proposition that refers to the practical

6. See Ehrenberg (2010) and Marquis (2012) for a presentation of these connections. 
anthropology and cosmology described earlier. From their points of view, the role of the politician who has failed in his mission of staving off a world in crisis and is now part of the "system» from which we must escape to have hopes of a change coming about, is limited to that of setting up the conditions of this individual action ${ }^{7}$ based on each person's inner resources, to the extent that this individual action seems to be the only believable, even possible, way out.

But how is it possible not to see that in these grammars, the most probable, the most effective agent of change is ultimately taking individual responsibility, for which indeed our respondents are clamouring? And that each of us can and must give proof of this by taking charge of ourselves for our own benefit as well as for the common good? ${ }^{8}$ How can we overlook the fact that the respondents seem to make the advent of a new world a matter of individual efforts and of aggregated personal determination? How, consequently, can we fail to grasp the proximity between the conventional representation of the market (based on autonomous individuals who own their liberty and act according to their consciences) and the idea that social change will result from the aggregation of individual changes (or those made by small groups) in our representations and mentalities?' ${ }^{9}$ Would not the world be better if it finally returned to a society of fundamentally good and responsible, free individuals, which would end up in getting each of us to work upon ourselves? Autonomy, individual responsibility, effectiveness, personal effort, freedom, mentality (and also the

7. This is what the vocabulary of «empowerment» expresses. To illustrate this, we can point out that $91.2 \%$ of the respondents agreed with the idea that «The State should put subjects such as better self-understanding and relations with others on the same footing as academic knowledge and training». This can be heard as a distant echo of the liberal philosopher Benjamin Constant's maxim celebrating the «negative freedom» of the Moderns: «Let them [government] confine themselves to being just. We shall assume the responsibility of being happy for ourselves» (1819). It is thus important to see that the political sphere has not been totally abandoned by the respondents. Rather, it remains an important regulatory factor (and they continue to make many demands of it and to criticise it for its assumed inability to fulfil these missions). What they do seem to have lost faith in, however, is the political sphere's ability to back a plan of substance for society (or a utopia).

8. Moreover, this exact same idea triggers reams of reactions when it is applied in the world of business, or in the «active social Welfare State», where individuals are gauged by their ability to take charge of themselves. Indeed, it is interesting to note that only $13.9 \%$ of the respondents to this survey stated that they did not agree with the proposition «I think that when it comes to all the people in difficulty, the community should help first those who are doing their utmost to get by».

9. This vision is not at all new; a typical formulation of it can be found in the New Age current (Garnoussi, 2007). 
power to think), and so on: this is indeed the vocabulary of liberalism, and it is mobilised in manifestations of liberalism that we perceive as desirable at certain times and detestable at other times.

\section{Conclusions}

These grammars attest to ways of expressing worries and hopes that are specific to individualistic societies (for which the individual is the supreme value $\left.^{10}\right)$. However, isn't the «ambient individualism» precisely what is incriminated in the grammars present in lay discourse (and in certain scientific writings) as the cause of the crisis? According to Ehrenberg (2010), there is nothing paradoxical in that. In comparing the United States and France he managed to advance the hypothesis that criticising individualistic societies, that the fear of the possibility of living together's melting away, is consubstantial with such societies' functioning. Becoming aware of this does not by any means disqualify this criticism any more than it justifies it.

Recognising that the grammars of change are situated in a liberal moral context makes it possible, however, to shed a different light on the issue of depoliticisation. This term must not be understood as qualifying a withdrawal from action, but rather as disqualifying certain forms of action, mainly collective ones. It also shows that whilst fingers are often pointed at «liberalism» in everyday parlance, we cannot detach ourselves so easily from its vocabulary and representations, which we have learnt to love over the centuries. So, even the formulation of indigenous utopias (as they are commonly understood) cannot do without them. On the contrary, it draws inspiration from there to imagine what both «the good life» and «living together in the world» should look like.

\section{References}

ANDERS, G. (2008): Hiroshima est partout, Paris, Seuil.

BECK, U. (2001): La société du risque. Sur la voie d'une autre modernité, Paris, Éditions Aubier.

10. «A society is individualistic when it gives the same value to all human beings. That is the foundation of living together in these societies, in the sense that this value is the supreme value» (Ehrenberg, 2010: 141). 
Boltanski, L. (2009): De la critique. Précis de sociologie de l'émancipation, Paris, Gallimard.

Boltanski, L.; E. Chiapello (1999): Le nouvel esprit du capitalisme, Paris, Gallimard.

Bourdieu, P. (1998): «L'essence du néolibéralisme», Le Monde diplomatique, March. <http://www.monde-diplomatique.fr/1998/03/BOURDIEU/10167>, [1/4/2014].

CASTEl R. (1981): La gestion des risques, de l'anti-psychiatrie à l'aprèspsychanalyse, Paris, Éditions de Minuit.

Castoriadis, C. (1975): L'Institution imaginaire de la société, Paris, Éditions du Seuil.

De LaRA, P. (2008): «Anthropologie du totalitarisme. Lectures de Vincent Descombes et Louis Dumont», Annales. Histoire, Sciences Sociales, 2: 353-375.

De Munck, J. (1999): L'institution sociale de l'esprit. Nouvelles approches de la raison, Paris, Presses universitaires de France.

Descola, P. (2005): Par-delà nature et culture, Paris, Gallimard.

Dumont, L. (1976): Homo aequalis, Paris, Gallimard.

Ehrenberg, A. (2010): La société du malaise, Paris, Odile Jacob.

Foessel, M. (2012 a): «La raison de l'apocalypse» in Critique, 783-784: 666676.

- (2012 b): Après la fin du monde, Paris, Seuil.

FripPiat, D.; N. Marquis (2010): «Web Surveys in the Social Sciences: An Overview», Populations, 65 (2): 309-338.

GaRnoussi, N. (2007): De nouvelles propositions de sens pratiques dans le domaine de l'existentiel: etude sociologique de la nebuleuse psychophilo spirituelle, Ph.D. thesis in religion, constructs, and sociology, Paris, EPHE.

GaUChet, M. (1985): Le Désenchantement du monde. Une histoire politique de la religion, Paris, Gallimard.

- (1990): «Sous l'amour de la nature, la haine des hommes», Le Débat, 60: 57-72.

Herzlich, C. (1969): Santé et maladie. Analyse d'une représentation sociale, Paris, EPHE / Mouton.

ILLOUZ, E. (2008): Saving the modern soul: therapy, emotions, and the culture of self-help, Berkeley, University of California Press.

LeCourT, D. (2003): Humain post-humain, Paris, Presses universitaires de France. 
LEMAîTRE, F. (2009): «La tentation du retour du malthusianisme», Le Monde, 26 November. Digital Edition.

LeVi-Strauss, C. (1950): «Introduction à l'oeuvre de Marcel Mauss» in MAUSS, M., Sociologie et anthropologie, Paris, PUF.

LORDON, F. (2009): La crise de trop - Reconstruction d'un monde failli, Paris, Fayard.

- (2011): D’un retournement l'autre - Comédie sérieuse sur la crise financière - En quatre actes, et en alexandrins, Paris, Seuil.

Marquis, N. (2012): Sociologie de la pratique de lecture du «développement personnel» en régime d'autonomie: du texte à l'expérience, $\mathrm{Ph} . \mathrm{D}$ thesis in political and social science, Brussels, Université Saint-Louis.

Martin, O. (2009): L'Enquête et ses méthodes: l'analyse de données quantitatives, Paris, Armand Colin.

Musso, P. (2010): «De la socio-utopie à la techno-utopie», Manières de voir. Le Monde diplomatique, 112: 6-10.

SloterdiJK, P. (1987): Critique de la raison cynique, Paris, Christian Bourgeois.

STEngers, I. (2009): Au temps des catastrophes. résister à la barbarie qui vient, Paris, La Découverte.

Vielle, P.; P. Pochet; I. Cassiers (eds.) (2005):L'état social actif. Vers un changement de paradigme?, Brussels, Editions Peter Lang.

Wittgenstein, L. (2004): Recherches philosophiques, Paris, Gallimard. 